\title{
The profits of being bankrupt
}

\section{The Manville Corporation is using the US bankruptcy laws legally but too cleverly to avoid costly damage suits from asbestos workers. It needs help from Congress.}

MANVILLE Corporation is by all accounts the most profitable bankrupt company in history. One year ago this week, Manville filed for bankruptcy to the astonishment of the financial world and the outrage of thousands of asbestos workers who were suing or preparing to sue the former asbestos-manufacturing giant for the damages they suffered from breathing asbestos fibre. Under the bankruptcy court's protection, Manville has freed itself from all immediate obligations, has blocked the filing of new lawsuits against it (which were coming in at the rate of 400 per month at the time it declared bankruptcy) - and has accumulated a phenomenal pile of cash and securities. The latter is probably not surprising in light of the fact that Manville was a profitable enterprise even as it was declaring itself bankrupt (operating income of $\$ 43$ million during the first six months of last year), and has become all the more profitable with its debt obligations frozen. Still, it is sobering to discover just how well the company is doing. Its holdings of cash and marketable securities have grown to $\$ 233$ million from $\$ 27$ million a year ago. And its operating income for the first six months of this year is nearly double last year's level.

The outcry that greeted Manville's bankruptcy filing specifically, the accusation that a financially healthy company was abusing the bankruptcy process to duck its legal obligations to asbestos victims - has not penetrated very deeply into the company's apparently thick hide. The company has already missed six court-ordered deadlines for filing a reorganizaton plan, as required by the bankruptcy law, and is not expected to meet the latest deadline of 15 September. The company's vice-president was in fact quoted in the New York Times last week as saying that it might take two years for a plan to be worked out. The company cannot complain if its critics conclude that Manville's chief concern is prolonging to the limit its stay in legal never-never land.

The company's plan for reorganization foresees splitting the company into two parts: one will contain the money-making building-products business; the other will do nothing but handle asbestos claims. The plan deserves an award for sheer audacity if nothing else.

The issue of Manville's culpability - or, more to the point, its liability - is, to be sure, far from cut and dried. The apportionment of liability is largely a matter of common law - that is, judicial precedent - and over the past 60 years in the United States the courts have placed dramatically increased responsibility for the safety of a product on the manufacturer. Until the 1920 s, produce liability claims had to be based on a warranty. A landmark suit against Buick changed that when the court ruled that negligence on the manufacturer's part was sufficient grounds. More recently, courts have held manufacturers to a standard of strict liability in some cases, which drops even the negligence requirement. Strict liability is based in part on the legal theory that the manufacturer is best able to bear the social cost of damage done, regardless of who is at fault.

Manville's position is complicated by the role of the US Government during the Second World War in directing the manufacture of asbestos and its use in shipbuilding. Roughly half of the 20,000 claims filed against Manville involve workers at wartime shipyards that were either owned by the government or under direct government control or contract, and Manville recently sued the government to recover the costs of some of its settlements with these workers. The company has produced some damning government documents from the period which appear to support its case that the government was aware of an asbestos hazard at these facilities.

The resolution of this issue is unquestionably a matter for the courts, and Manville is well within its rights and the bounds of propriety to seek, through a lawsuit against the government, a judicial determination of where the liability lies. It would likewise be appropriate for industry as a whole to seek a legislative declaration of how, generally, liability is to be apportioned in a world that we should know by now cannot be risk-free. The social policy question of who should and is best able to bear the costs of injury to workers or consumers is indeed not one that should be left by default to the courts.

The tactical use of bankruptcy protection by a profitable company is quite a different matter. By continuing to hide under the protection of the court and by dragging the proceedings on as long as possible, Manville's appeal for a judicial finding of the government's share of liability becomes hypocritical at best. And in the long run, such hypocrisy can only harm the prospects for a much needed statutory adjustment of the assignment of risk.

\section{Star wars treaty?}

The Reagan Administration has been too quick to reject the Soviet draft of a treaty on space weapons. SHOuld there be a formal treaty banning the use of bows and arrows for military purposes? Or one that would for all time outlaw the use of telehypnotism (long-distance mind control on which dedicated teams of parapsychologists are working in secret) as a means of subverting political leaders' resolution? And how should responsible governments respond when fellow governments submit draft treaties for these purposes to the United Nations? Luckily, several centuries of diplomacy have provided all the language needed to deal with awkward questions such as these. Unhappily, none of this was evident in the sour response from Washington to Mr Yuri Andropov's draft treaty on space weapons (see page 3 ).

Mr Andropov's proposed treaty is, of course, serious - for which reason it might have been expected to have evoked a serious response. As things are, the only feasible applications of star wars technology are in the destruction of other people's military satellites, presumably at the outset of hostilities of some kind. President Ronald Reagan has, however, been advocating research and development aimed at the unfeasible goal of perfect defence against ballistic missiles. Mr Andropov's draft treaty is a valid, if cheeky, counter-move. The Reagan Administration seems not to appreciate that dismissing it, with hints that the Soviet Union is in any case "ahead" in the development of antisatellite weapons, is a false move. A workable treaty on space weapons would be well worth having, for these devices are neither bows and arrows nor telehypnosis. The assertion is also false that negotiations on a space treaty would distract attention from the more important negotiations of missiles (intermediate and long-range) still (mercifully) dragging on in Geneva. The truth is probably the opposite. Any treaty, on almost any subject, would help people to sustain hope that something will come from the Geneva negotiations. 